\title{
Ethics in the Built Environment (EiBE)
}

\section{- A Challenge for European Universities -}

\author{
Prof. Dr. Carsten Ahrens \\ Department of Civil Engineering and Geoinformation \\ Fachhochschule Oldenburg/Ostfriesland/Wilhelmshaven (FH OOW) \\ Oldenburg, Germany \\ e-mail: carsten.ahrens@fh-oldenburg.de
}

\section{Summary}

The SOCRATES Intensive Project „Ethics in the Built Environment (EiBE) - A Challenge for European Universities -“ should bring and mostly brought together students and teaching staff of 15 European universities from South (Porto, Portugal; Valencia, Spain; Patras, Greece) to North (Tampere, Finland; Tallinn, Estonia; Kaunas, Lithuania; Halmstad, Sweden) and from West (Galway, Ireland; Wolverhampton, United Kingdom; Groningen, Netherlands; CachanParis, France; Oldenburg, Germany) to East (Stettin, Poland; Prague, Czech Republic; Budapest, Hungary) and in the first respective last year from Moscow, Russia, and Changchun, China.

The three years programme offered a forum to discuss the different approaches to define „Ethics in the Built Environment" from both the teaching and learning sides and in connection with professional bodies. Its aim was to provide a sound platform of common understanding about ethics in this context and to work out a common module as part of the education of young civil and construction engineers at the involved universities. - SOCRATES is a powerful EUprogramme that supports under the sub-name ERASMUS numerous co-operation programmes between European universities [1].

\section{Background}

At least there are two backgrounds, the student's and the employed engineer's view.

Students of the FH OOW who go to a foreign country and foreign students who come to Oldenburg now not only realize that there are different sociological and cultural conditions in the host countries and different teaching and studying conditions at the partner universities. Meanwhile this is European students' common knowledge, which has been given to them by

"Proceedings of the 2004 American Society for Engineering

Ecucation Annual Conference \& Exposition

Copyright@2004,American Society for Engineering “ 
their predecessors. And so, it is well known by students of other universities, too, especially when coming from partner universities.

But what students of civil and construction engineering are stating - in a growing amount and with sharper contours - especially during their practical placements is the other way of working and solving the problems of daily work on the construction site and in the offices. It is not the technical aspect but the intercourse with partners and clients. So it is

- the co-operation with colleagues and the public,

- the liability in contracting and

- the thrilling field between technical possibilities and demands of the environment etc.

which causes disbelief or even uncertainty.

Young future civil/construction engineers and managers are seeing themselves in a situation on which they cannot react in a proper way because of their up to now only technically oriented education.

But also experienced civil/construction engineers, supervisors of building sites and building or project managers are envisaging above their normal technical requirements numerous demands of different culture, working moral, ethical values, environmental responsibility etc.

The mentioned forcing requirements will be overtaken individually depending on the personal status and behaviour. But not only in a uniting Europe with corresponding European wide working possibilities it is necessary to do the job apart from pure individual solutions but on a strong basis of commonly respected measures of higher education, practical experience, continuous professional development and, not at least, of professional conduct.

\section{The status quo}

The European Union (EU) has partly opened and intends to open totally the borders between the member states to all professionals, especially to civil/construction engineers (see Proposal for a Directive of the European Parliament and of the Council on the recognition of professional qualification, 2002/0061 (COD), Brussels, 07.03.2002 [2]). A civil engineer who wants to settle down and to make up his own professional office in a foreign country - or offering services to the public - has to undergo the national restrictions and professional requirements of the national bodies or civil engineering associations. And at least, he or she has to sign regulations of professional conduct as developed by the national professional institutions. In this IP it was this topic to deal with.

The „European Council of Civil Engineers (ECCE)“ is an association of about 25 national civil/construction engineering associations which can be treated as the voice of the European civil/construction engineers [3]. When working in the ECCE Task Force „Professional Recognition“ it turned out that the subject „Ethics in the Built Environment" is understood in a

"Proceedings of the 2004 American Society for Engineering

Ecucation Annual Conference \& Exposition

Copyright@2004,American Society for Engineering “ 
very diverging manner, has many different facettes of regional, cultural, geographical, lingual aspects etc. but is a necessary part of a European wide mutual recognition of professionals. In the whole field of education of engineers in Europe there exists a very detailed description of equivalency of the status of an engineer (see FEANI [4]) and the necessary education and training demands (see SEFI [5]), but it concerns more or less only the technical aspects.

Concerning civil/construction engineering of professionals there is the European Council of Civil Engineers ( ECCE) which states some few general requirements on the education and expertise profile of engineers in the built environment. But ECCE places aside a code of professional conduct the recognition of which is the basis for acceptance to be a member of a proposed Register of European Engineers of the Built Environment and, thus, gives the supposition for a European wide work permit.

\section{General aims and purposes of the IP}

The herewith described Socrates Intensive Project "Ethics in the Built Environment (EiBE)" did not deal with the technical aspects of engineering education. But it came up with the idea of ECCE in that way that the participating partner institutions shall form a catalogue of codes or contents of conducts according to a given frame at home which shall be summarized during the IP-meetings into a common catalogue.

The idea behind this project, too, is that young civil/construction engineering students shall discuss this topic on a stage before employment and, thus, before being too much engaged in companies' and employers' strategies and - sometimes - economic and social restrictions. To get a better European aspect this project brought together about 50 students and lecturers from all together 15 different European and two international partner universities, their respective civil engineering departments, employed engineers of construction companies and members of engineering societies and the public.

It is obvious that the students have different thoughts about ethical rules in their future job, that they have different understandings of words and their contents. So, it was necessary to collect the variety of understandings and to make up a common basic vocabulary. On this basis of common understanding the module "Ethics in the Built Environment" has been roughly formed or shaped during the first IP-meeting, which took place at FH OOW in Oldenburg in September 2001, and has got much sharper contours in the Prague 2002 and Porto 2003 meeting [6].

\section{Course Content}

The Socrates Intensive Project „Ethics in the Built Environment (EiBE)“ aimed to build up an English-language module „Ethics in the Built Environment“ which could or better should find use as obligatory part in the civil engineering education at European universities.

The module is to last one semester with 15 lecturing weeks, containing 2 (or later 4) lecturing hours per week and be valued with a certain amount of ECTS-credit points ( 2 to 5 credits).

\footnotetext{
"Proceedings of the 2004 American Society for Engineering Ecucation Annual Conference \& Exposition Copyright@2004, American Society for Engineering“
} 
The set-up of the module is orientated to the German VDI (Association of German Engineers) guidelines VDI 3780 [7] and to the Professional Code of Conduct of the European Council of Civil Engineers (ECCE) [3].

\subsection{Proposed semester plan of module Ethics in the Built Environment}

1. week General introduction into the subject, definitions

2. week Ethics and philosophical development

3. week The importance of value systems, in general life and in technology

4. week Values in technical action: functionality

5. week Values in technical action: economy

6. week Values in technical action: prosperity

7. week Values in technical action: safety

8. week Values in technical action: health

9. week Values in technical action: environmental quality

10. week Values in technical action: personality development and social quality

11. week Correlation between values, types and phases of evaluation of technology

12. week Special problems in the built environment

13. week The civil engineer and the public

14. week Chances of ethical rules as part of the building company's

firm structure and strategy

15. week International context and in-depth revision

(16. week Examen, assessment, ..., if needed, possible, wanted)

\subsection{Structure of lessons}

Each lesson shall consist at least of 90 minutes or 2 lecturing hours (better 2 x 90 minutes or 4 lecturing hours) and could show the following structure:

1. Revision of last week/lesson with small assessment/test $15 \mathrm{~min}$.

2. Introduction (theoretical lecture) to today's topic $15 \mathrm{~min}$.

3. In-depth discussion in plenum/class $15 \mathrm{~min}$.

4. List of words relevant to context (home language and English) $5 \mathrm{~min}$.

5. Power Point presentation (in English) with discussion

(very distinctive, creative, critical, sophisticated etc.) $15 \mathrm{~min}$.

6. Case study or role play or ... in English with discussion

(very provocative, with structures to think about, different levels, not black or white, ...), work in groups

$25 \mathrm{~min}$.

In case of a lecturing time of 4 hours per week

7. Group work on all points 1 . to 6. resulting in deepening the general ideas and transferring the respective national presentations into ,own applications“ (this work should be accompanied by members of the building industry, professional bodies, the public etc.)

$90 \mathrm{~min}$.

"Proceedings of the 2004 American Society for Engineering

Ecucation Annual Conference \& Exposition

Copyright@2004, American Society for Engineering “ 


\section{Development of and universities' involvement in the module project}

The three summer courses of the IP consisted of about 10 working days each. At least 30 contact hours in the whole assembly e.g. students and teachers together have been assigned and at least another 30 hours have been used for working in groups; this amounts to a number of more 60 working hours. Taking into account also cultural arrangements, intercultural events and work in the public (podium discussion etc.) the IP would come up to about 2 ECTS credit points in the student learning life.

The participants are given a certificate each year for successful completion of the project or a part of it. Some of the participating institutions are granting this certificate with the above mentioned 2 credit points. - This type of creditation was necessary once to attract students and to give pedagogical value to them and the involved institutions and secondly to please the Socrates office.

To gain a better continuity in the project it was intended to involve mostly students of the first (undergraduate) study years and of the former project year to have the possibility of letting them work also in the following project year(s).

In addition it was always an aspect of quality and equivalence of the project to have a diversified European composition. But as it happens always in international projects between institutions of higher education there are more or less active and interested students and more or less active and financially interested and supporting cooperation partners.

And thirdly all participating institutions had to verify their interest in this IP in such a way that they paid about $50 \%$ of the travelling and living costs for their participants, students and teachers. And they had to agree in a very early stage of the project, at least one year before getting it granted, to the following rough schedule of it.

\begin{tabular}{|l|l|}
\hline Year & Programme \\
\hline 1. Project year & $\begin{array}{l}\text { Creating a list of ethical rules and an international vocabulary } \\
\text { 1. version of the module in coordination with national engineering } \\
\text { associations and building industry partners }\end{array}$ \\
\hline 2. Project year & $\begin{array}{l}\text { Evaluation and revision of rules and module } \\
\text { 2. version of the module in coordination with national engineering } \\
\text { associations and building industry partners }\end{array}$ \\
\hline 3. Project year & $\begin{array}{l}\text { Production of the final version of the module "Ethics in the Built } \\
\text { Environment (EiBE)"to be used in the civil engineering course work } \\
\text { - in the institutions of the participating partners and } \\
\text { - in other institutions of higher education of the EU } \\
\text { as a module with example character or hopefully of "excellence" in } \\
\text { education of civil/construction engineers }\end{array}$ \\
\hline
\end{tabular}

Table 1. Overview of the three years work programme and its proposed results

\footnotetext{
"Proceedings of the 2004 American Society for Engineering Ecucation Annual Conference \& Exposition Copyright@2004,American Society for Engineering “
} 


\section{Preparation work of participants}

Before the meetings all participants had to prepare a paper on one of the sub-numbers of the above mentioned ECCE code of professional conduct and/or values in technical actions. This code has been sent to them or to their lecturers some months/weeks before the meeting together with a literature list $[3,7-15]$.

So, the students have been invited to participate in the project but only after having worked out a paper of about 6 DIN-A4 pages or short presentations, brief lectures etc. on the selected topic. The results of them have been judged by the respective colleagues and have been sent to the coordinator via e-mail or by letter. The best authors out of these groups ( 2 up to 4 students) participated in the projects in Oldenburg 2001, in Prague 2002 and in 2003 in Porto.

An example of the preparation work is given by the following Porto 2003 working list:

1. Introduction (theoretical lecture) to „today's“ topic

2. List of vocabules relevant to context, completion of multilingual vocabulary

3. Power Point presentation (in English) (very distinctive, creative, critical, sophisticated etc.)

4. Case study or role play or ... in English (very provocative, with structures to think about, etc.)

The presentation of not less than 20 minutes should also include aspects of the actual discussion concerning ethics ,,at home“. The presentation should be given by students themselves and only with assistance of the respective lecturers.

According to the European idea the partners had to prepare their additional specific presentation due to the following list which was for the Porto summer course:

Oldenburg, Halmstad Values in technical action: functionality

Valencia Values in technical action: economy

Tallinn, Budapest Values in technical action: prosperity

Stettin

Prague, Kaunas

Tampere, Porto

Values in technical action:

Values in technical action:

Values in technical action:

safety

health

environmental quality

At the first two meetings the papers are presented and discussed in the plenum. In working groups specific thematic points have been worked out and presented twice during the project period. The presentations were usually paper presentations but they had to be "completed" by power point presentations, video role play presentations and case studies which have to be performed in front of the audience during the respective summer course [6].

The aims for the student's work and involvement have always been to develop material for the IP to fill a 30-page booklet at least in the working languages English and German which includes thesis, working sheets, question and answer lists, multilingual vocabulary, and to produce additional video recordings and role plays (also on DVD), CD-presentations etc.

\footnotetext{
"Proceedings of the 2004 American Society for Engineering

Ecucation Annual Conference \& Exposition

Copyright@2004,American Society for Engineering“
} 


\section{Co-operation partners}

Each of the universities taking part in this European Socrates Intensive Project are working closely together with the building industry, building authorities, engineering associations and chambers of engineers, which have been involved especially in the third project year as partners. In all three project years members of these professional institutions have been involved in personal consulting, but not yet the institutions themselves.

The following institutions of higher education are involved in this program:

\begin{tabular}{|l|l|l|l|}
\hline Name & Short & $\begin{array}{l}\text { Coun } \\
\text { try }\end{array}$ & Tasks and responsibilities \\
\hline $\begin{array}{l}\text { Fachhochschule } \\
\text { Oldenburg/ } \\
\text { Ostfriesland/ } \\
\text { Wilhelmshaven }\end{array}$ & $\begin{array}{l}\text { FH } \\
\text { OOW }\end{array}$ & DE & $\begin{array}{l}\text { Co-ordinator, organisation, } \\
\text { scientific work, international } \\
\text { organisation, pedagogical care, } \\
\text { translation care, communication, } \\
\text { video-recording, homepage }\end{array}$ \\
\hline Tampere Technical Institute & TT & FI & University co-ordinator, TN \\
\hline Hogeschool Halmstad & HH & SE & University co-ordinator, TN \\
\hline Technical University of Stettin & TUoS & PL & University co-ordinator, TN \\
\hline Czech Technical University of Prague & CVUT & CZ & University co-ordinator, TN \\
\hline College Technical Engineering Tallinn & TCET & EE & University co-ordinator, TN \\
\hline Kaunas Technical University & KTU & LIT & University co-ordinator, TN \\
\hline $\begin{array}{l}\text { Gödöllö University Ybl Miklos, } \\
\text { Budapest }\end{array}$ & YMMF & HU & University co-ordinator, TN \\
\hline $\begin{array}{l}\text { Ecoles Superior de Traveaux Public, } \\
\text { Cachan }\end{array}$ & ESCIT & FR & \\
\hline Hanzehogeschool van Groningen & HvG & NL & - \\
\hline University of Wolverhampton & UoW & UK & - \\
\hline Galway Mayo Institute of Technology & GMIT & IRL & - \\
\hline TEI Patras & TEIPAT & GR & University co-ordinator, TN \\
\hline University of Valencia & UPV & ES & University co-ordinator, TN \\
\hline University of Porto & UoP & PT & University co-ordinator, TN \\
\hline
\end{tabular}

Table 2: Participating universities and their tasks (TN means participant with students/teachers)

\section{Relationship between "EiBE" and existing courses and the outcomes}

At all partner universities, which are involved in this project, civil engineers, building and project managers (at national and international courses) and building economy engineers are educated as full-time or part-time students. The problem of envisaging other social values and working conditions and socio-economic and ethic working attitude at foreign places in the Built Environment and of employment, applies to all the students from all partner universities.

\footnotetext{
"Proceedings of the 2004 American Society for Engineering Ecucation Annual Conference \& Exposition Copyright@2004,American Society for Engineering “
} 
All partner universities are seeing the necessity of a corresponding preparation and education of "other" values and are preparing and using such modules as optional modules, but some also put them in the compulsory sector of the civil/construction engineering study programme. Up to now there is still a real differenced spectrum of teaching ethics. Most of the partners have no real "pure" module for ethics in their curriculum. They say "they distribute it into all the normal lectures" which is "hiding away these aspects" as students argue.

The participating lecturers are still responsible for the local co-ordination and dissemination; they still have to address this topic to the students of their courses and to make them interested in the project results. The interest in the project has been and will be intensified by the possibility to visit the respective websites of the partner institutions.

The pedagogic aspect of the specific sections still consists - and will consist - of the importance of ethical questions in the later employment of the students. Students hopefully will ask their lecturers and professional civil engineers and building managers for their opinions during their education at the university and their practical placement as part of the curriculum.

They may find some important help for answering such questions in the results of the common Socrates IP EiBE at the FH OOW as the co-ordinator of this project which comprises the results of the single partner universities and works out a compendium of ethical rules of engineers in the built environment. As the most important part of the project the module" Ethics in the Built Environment" will be composed out of these instructions and working outcomes which unites a good number of different national understanding of ethics. So this module will be based on European views and experiences of the different partner aspects and, thus, shall summarize these in a European module as an interactive and student organised and oriented lecturing event.

Keywords: ethical values in engineering, international teaching of ethics, mobility of students and professionals, European internal market

\section{Bibliographic information}

1. www.europa.eu.int/comm/education/programmes/socrates/erasmus/erasmus en.html

2. www.europarl.eu.int/activities/default_en.htm

3. ECCE code of professional conduct, Rome 2000, www.eccenet.org

4. www.feani.org/esoepe

5. www.ntb.ch/SEFI/bolognadec.html

6. www.fh-oldenburg.de/oow/aka/socra/

7. VDI regulation 3780, Technology Assessment, Concepts and Foundations, Beuth-Verlag, Berlin, 2000

8. Friedrich Stähli, Ingenieur-Ethik an für Fachhochschulen - ein Leitfaden, Aurau, CH, 1998

9. Ethics and Technology, Herman T. Tavani, J. Wiley and Sons, 2004, ISBN 0-471-24966-1

10. Ethics in Engineering, Mike W. Martin, Roland Schinzinger, McGraw-Hill, 1997, ISBN 0-07-040849-1

11. Fundamentals of Ethics, Edmund G. Seebauer, Robert L. Barry,

Oxford University Press, 2001, ISBN 0-19-513488-5

\footnotetext{
"Proceedings of the 2004 American Society for Engineering

Ecucation Annual Conference \& Exposition

Copyright@2004,American Society for Engineering“
} 
12. Introduction to Engineering Ethics, Roland Schinzinger, Mike W. Martin

McGraw-Hill, 2000, ISBN 0-07-233959-4

13. Engineering Ethics, Charles B. Fleddermann, The Prentice Hall, 1999, ISBN 0-13-784224-4

14. Environmental Ethics Today, Peter S. Wenz, Oxford University Press, 2001, ISBN 0-19-513384-6

15. A Practical Companion to Ethics, Anthony Weston, Oxford University Press, 2002, ISBN 0-19-514199-7

\section{Biographical Information}

Prof. Dr. Carsten D. Ahrens, born 04.01.1944

Department of Civil Engineering and Geoinformation

Professor for Mathematics, Building and Environmental Physics, Technical Mechanics

Fachhochschule Oldenburg/Ostfriesland/Wilhelmshaven (FH OOW) since 1975

Tel. ++49-441-7708-3391, Fax ...-3115, e-mail: carsten.ahrens@fh-oldenburg.de 